\title{
Risk factors for the incursion, spread and persistence of the foot and mouth disease virus in Eastern Rwanda
}

Jean Claude Udahemuka ${ }^{1,2^{*}}$ (D), Gabriel Oluga Aboge ${ }^{1,3}$, George Ogello Obiero ${ }^{1}$, Phiyani Justice Lebea ${ }^{4}$, Joshua Orungo Onono ${ }^{3}$ and Massimo Paone ${ }^{5}$

\begin{abstract}
Background: Identification of risk factors is crucial in Foot-and-mouth disease (FMD) control especially in endemic countries. In Rwanda, almost all outbreaks of Foot-and-Mouth Disease Virus (FMDV) have started in Eastern Rwanda. Identifying the risk factors in this area will support government control efforts. This study was carried out to identify and map different risk factors for the incursion, spread and persistence of FMDV in Eastern Rwanda. Questionnaires were administered during farm visits to establish risk factors for FMD outbreaks. Descriptive statistical measures were determined and odds ratios were calculated to determine the effects of risk factors on the occurrence of FMD. Quantum Geographic Information System (QGIS) was used to produce thematic maps on the proportion of putative risk factors for FMD per village.
\end{abstract}

Results: Based on farmers' perceptions, $85.31 \%$ (with $p<0.01$ ) experienced more outbreaks during the major dry season, a finding consistent with other reports in other parts of the world. Univariate analysis revealed that mixed farming $(\mathrm{OR}=1.501, p=0.163, \mathrm{Cl}=95 \%)$, and natural breeding method ( $\mathrm{OR}=1.626 ; p=0.21, \mathrm{Cl}=95 \%)$ were associated with the occurrence of FMD indicating that the two risk factors could be responsible for FMD outbreaks in the farms. The occurrence of FMD in the farms was found to be significantly associated with lack of vaccination of calves younger than 12 months in herds ( $\mathrm{OR}=0.707 ; p=0.046, \mathrm{Cl}=95 \%)$.

Conclusions: This is the first study to describe risk factors for persistence of FMDV in livestock systems in Rwanda. However, further studies are required to understand the role of transboundary animal movements and genotypic profiles of circulating FMDV in farming systems in Rwanda.

Keywords: Foot-and-mouth disease, Risk factors, Maps, Geospatial, QGIS, Eastern Rwanda, Foot-and-mouth disease spread

\footnotetext{
* Correspondence: j.udahemuka@ur.ac.rw

${ }^{1}$ Centre for Biotechnology and Bioinformatics, University of Nairobi, P.O. Box 30197, Nairobi, Kenya

${ }^{2}$ Department of Veterinary Medicine, University of Rwanda, P.O. Box 57,

Nyagatare, Rwanda

Full list of author information is available at the end of the article
}

(c) The Author(s). 2020 Open Access This article is licensed under a Creative Commons Attribution 4.0 International License, which permits use, sharing, adaptation, distribution and reproduction in any medium or format, as long as you give appropriate credit to the original author(s) and the source, provide a link to the Creative Commons licence, and indicate if changes were made. The images or other third party material in this article are included in the article's Creative Commons licence, unless indicated otherwise in a credit line to the material. If material is not included in the article's Creative Commons licence and your intended use is not permitted by statutory regulation or exceeds the permitted use, you will need to obtain permission directly from the copyright holder. To view a copy of this licence, visit http://creativecommons.org/licenses/by/4.0/ The Creative Commons Public Domain Dedication waiver (http://creativecommons.org/publicdomain/zero/1.0/) applies to the data made available in this article, unless otherwise stated in a credit line to the data. 


\section{Background}

Foot-and-Mouth Disease (FMD) is a highly contagious viral disease caused by a picornavirus known as Footand-Mouth Disease Virus (FMDV) [1]. FMD affects cloven-hoofed animals including domestic and wild animals [2]. Cattle, sheep, goats and pigs are the most important domestic animals affected by the disease. In wildlife, at least 70 species of wild and captive animals including African buffaloes (Syncerus caffer) are affected [2]. The East African region is considered to have the most complicated situation with regard to the control of FMD. This is due to interactions between domestic and wild animals susceptible to FMD, uncontrolled transboundary animal movements and high genetic diversity of FMDV in the region [3]. The Akagera National Park (ANP) is home to many FMD susceptible wild animals, which are at of risk of interacting with livestock in farms adjacent to ANP. Rwanda has experienced many outbreaks of FMD with serotypes O reported in 1960, 1998, 2004 2008, 2009 and 2010 [4]. On the other hand, the first outbreak of SAT2 was reported in 1992 with the subsequent outbreaks being reported in 1996-1997, 2000-2001, 2004, 2005, 2006, 2008, 2009, 2010, 2013, 2015 and 2017 [4-9]. The other outbreaks of FMD involving serotypes A and SAT1 occurred in 2008, 2009, 2010 [9] and again serotype SAT1 in 2012-2013 [10].

Despite the reports of the previous outbreaks of the disease, little is known about risk factors responsible for these outbreaks. Understanding these risk factors is needed for the development of a Risk Assessment Plan necessary for the advancement in the Progressive Control Pathway for Foot-and-Mouth Disease (PCP-FMD) stages [11].

The Eastern Province of Rwanda is the largest province having $9813 \mathrm{~km}^{2}$ with a predominantly sedentary farming system. The livestock population in Eastern Province is composed of approximately 500,000 cattle, 500,000 goats, 13,000 sheep and 130,000 pigs [12]. This province neighbours Uganda and Tanzania and uncontrolled transboundary animal movements are likely to occur here. Moreover, the province receives low rainfall and is characterized by the absence of water bodies such as rivers. Consequently, many farmers in this province tend to use communal watering points thereby encouraging the congregation of animals and eventually contributing to the spread of FMD outbreaks [13]. In this regard, this area has been known to be a hotspot for most of the FMD outbreaks in Rwanda for the last two decades [12]. The dry season seems to be the period during which FMD outbreaks are more likely to occur in Eastern Rwanda and surrounding areas in Uganda and Tanzania [14-16]. During the dry season, there is a shortage of pasture and water; thereby forcing most livestock farmers to move their animals in search of pasture and water. This encourages contacts between infected and non-infected animals during an outbreak of FMD.

\section{Statement of the problem}

Nevertheless, fewer studies have been done to identify and map the risk factors responsible for FMD outbreaks in East Africa classified as FMD pool 4 where serotypes O, A, SAT1, SAT2 and SAT3 have been isolated [17]. Some of the risk factors which includes dry season and animal movements have been documented in Uganda and Tanzania [18-20]. Other putative risk factors, such as the use of shared bulls, for small-scale dairy farmers have also been reported in Kenya [21]. Despite these few studies in the region, none has been reported in Eastern Rwanda. We conducted questionnaire-based surveys in Nyagatare and Gatsibo districts of the Eastern province in Rwanda, known to be a hotspot for FMD outbreaks in the country [22] to investigate FMD risk factors.

\section{Purpose and what was done}

Comprehensive knowledge of risk factors is key in developing the Risk-Based Strategic Plan for the control of FMD required for achieving and maintaining the PCPFMD level 2 [11]. Therefore, from March 2018 to June 2018 we conducted surveys to investigate risk factors responsible for the incursion, spread and persistence of FMD in Eastern Rwanda. In addition, we produced thematic maps for a spatial understanding of these risk factors.

\section{Results}

We interviewed 184 farmers in 19 villages of Nyagatare and Gatsibo districts. However, considering that, some farmers did not answer all the required questions and hence unsuitable for analysis, we only exploited 143 responses. Among the 143 respondents, 36 (25.17\%) of them reported having had at least one FMD outbreaks within the last 5 years in their farms. There was no active outbreak of FMD in the visited farms during the interviewing period, the last outbreaks had occurred between May 2017 and February 2018 and were caused by serotypes SAT 2 [7]. During the outbreak, local veterinary officers collected oropharyngeal fluids, tissue and blood samples. The samples were shipped to the Virology laboratory of the Rwanda Agriculture Board to confirm the outbreak by Enzyme-Linked Immunosorbent Assay (ELISA) and Polymerase Chain Reaction (PCR).

\section{Vaccinating calves younger than $\mathbf{1 2}$ months}

By the time of our field visit, Rwanda has been vaccinating against FMD using FOTIVAX ${ }^{\text {tw }}$ from Kenya (KEVEVAPI) once a year. It is a trivalent vaccine containing serotypes $\mathrm{O}, \mathrm{SAT} 1$ and SAT2 with a recommendation of vaccinating 
twice or thrice a year for better protection [23]. We found that $57 / 142(40.15 \%)$ of farmers did not vaccinate calves which are younger than 12 months of age. Our results also showed an association between farmers reporting not to vaccinate calves under 12 months and FMD outbreaks in their herds $(\mathrm{OR}=0.707, p=0.046, n=137, \mathrm{CI}=95 \%)$ (Table 1).

\section{Presence of small ruminants}

In our study, small ruminants such as goats and sheep being kept together with cattle were reported in all villages as shown in the map below (Fig. 1a). Among the 143 respondents, only $13 / 143(9.09 \%)$ kept cattle only while 129/143 (90.21\%) reported mixed farms and one respondent did not answer to this question. Analyses showed that there are more chances $(\mathrm{OR}=1.501, p=$ $0.163, n=142$ and $\mathrm{CI}=95 \%$ ) for FMD outbreaks to occur when there are sheep and goats on the same farm (Table 2).

\section{Breeding methods}

We evaluated the impact of the breeding systems on the spread of the disease. We found that only 7 farmers out of 143 do use Artificial Insemination (AI) as a breeding method. Furthermore, the use of natural breeding methods increased the odds of FMD outbreak (OR = $1.626, \mathrm{CI}=95 \%)$ as compared to farms which were using AI as a breeding method ( $p=0.21, n=143)$ (Table 2). Due to the low number of farmers using AI, these results might be inconclusive and further analyses are necessary.

\section{Seasonality of FMD outbreaks and farming system}

In this study, we also determined the influence of seasonality on outbreaks of FMD. A majority (85.31\% with $p<$ $0.01, n=143$ ) of the farmers interviewed reported that FMD is more likely to occur during the major dry seasons (the major one from June to September and a less severe one from December to February) than in the wet season. These months coincide to what was reported by Kerfua et al. [16] and the OIE records [14, 24]. We found that the majority $(102 / 143[71.33 \%])(p<0.01)$ of the farmers practising semi-zero grazing system and fewer (40/ 143[27.97\%] practising strict zero grazing. No farmer responded to practice free-ranging system and one of the respondents did not provide an answer. Strict zerograzing was practised in three villages only. In other villages, the majority of cattle move daily in search of water and animals from different farms are more likely to congregate at watering points. Rwimiyaga, Kirebe, Kigezi, Bwera and Akanyange II villages located in Nyagatare district and Ndama village located in Gatsibo district have more than $75 \%$ of the farmers practicing semi-zero grazing (Fig. 1b). Not practicing zero grazing system does not significantly increase the outbreak occurrence, and cannot be considered as a risk factor in this case $(\mathrm{OR}=0.816, p=$ $0.274, \mathrm{CI}=95 \%$ ) (Table 2). In addition, farmers practicing zero grazing reported higher incidence of outbreaks than those practicing semi-zero grazing system (Table 3 ).

\section{Proximity of farms to each other}

We found that majority of the farms (140/143 [97.9\%]) were adjacent to at least another farm (Fig. 1c), a situation that can lead to increased transmission of FMD in case there is an outbreak in one of the farms. Some (3/ $143[2.1 \%])$ of the visited farms were not fenced. None of the three farms that were not adjacent to another farm reported having had an FMD outbreak in the previous 5 years. When tested against the criterion of either having had at least one FMD outbreak in the farm the results were not significantly exploitable $(\mathrm{OR}=0.773$, $p=0.659$ with $n=143$ and $\mathrm{CI}=95 \%$ ).

\section{Wildlife-livestock interface as a risk factor}

Of the 27 farms located in Akanyange II village of Nyagatare district, $88.9 \%$ of them were adjacent to the ANP, indicating that domestic animals from this village had the highest chances of interacting with wildlife (Fig. 2). Overall, 36/143 farms were adjacent to ANP. Among these, 11.1\% (4/36) reported having experienced FMD outbreaks in the previous 5 years against the remaining 88.9\% (32/36) who reported not to have had FMD in their farms in that period. The other group of farms (105/143), 30.5\% (32/143) reported having had FMD outbreaks while $69.5 \%(73 / 105)$ have not had FMD outbreaks in their farms in that period $(\mathrm{OR}=0.285, p=$ $0.028, \mathrm{CI}=95 \%)$.

\section{Maps of selected risk factors}

We mapped the risk factors such as farms that kept cattle, sheep and goats together (mixed farms), farming systems, non-fenced farms, closeness of various farms to each other and farms adjacent to the ANP. As shown in Fig. 1a, most of the farms in the villages had a mixed-

Table 1 Multivariable model for risk factors for the occurrence of FMD outbreaks in herds raised in Eastern Rwanda

\begin{tabular}{lllll}
\hline Parameter description & Estimate & Standard error & Significance & Odds ratio \\
\hline Intercept & 1.964 & 0.1336 & 0 & 7.13 \\
Vaccinate calves under 12 months & -0.347 & 0.1738 & 0.046 & 0.707 \\
Not vaccinating calves under 12 months & 0 & & \\
\hline
\end{tabular}



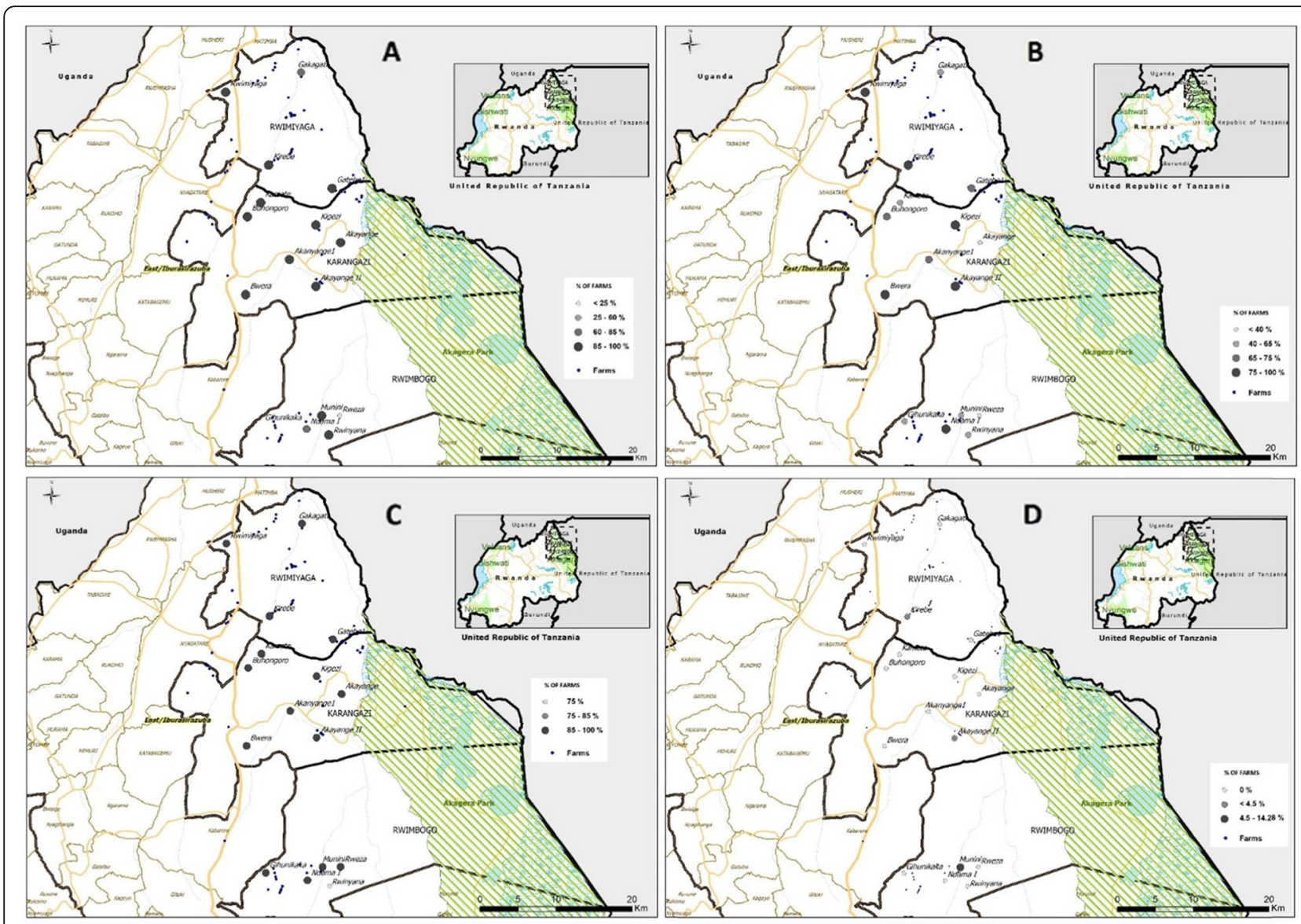

Fig. 1 a: Map showing the proportion of farms where small ruminants are kept together with cattle per village (map created using QGIS v. 2.18.22 (https://qgis.org/downloads/)). b: Map showing the proportion of farms practising semi zero-grazing and free-ranging in each village (map created using QGIS v. 2.18 .22 (https://qgis.org/downloads/)). c: Map showing the proportion of how farms are adjacent to each other in each village (map created using QGIS v. 2.18 .22 (https://qgis.org/downloads/)). d: Map showing proportion of the non-fenced farms in each village (map created using QGIS v. 2.18.22 (https://qgis.org/downloads/))

farming system (raising cattle, sheep and goats together) with 129 out of 143 (90.21\%) mixed farms. Mixed farms are evenly distributed throughout the Nyagatare and Gatsibo districts except for two villages in Nyagatare district, which had less than $85 \%$ of mixed farms. Figure $1 \mathrm{~b}$ shows the proportion of farms practising semi zero-grazing and free-ranging per village. Observation shows that villages near rivers would have more farms not practising strict zero-grazing ( $>75 \%)$. This is the case for Rwimiyaga, Kirebe, Kigezi, Akayange II and Bwera villages of Nyagatare district and Ndama I village in Gatsibo district.

As the Fig. 1d demonstrates, the fencing of the farms is well practised with an exception of Munini (>4.5\%) village of Gatsibo district having a higher percentage of unfenced farms when compared to other villages. Rwinyana village of Gatsibo district is the only one among all the villages with fewer farms $(<75 \%)$ that are not close to each other (Fig. 1c). Akayange I and Akayange II villages in Nyagatare district are the ones with a higher proportion of farms at the interface with ANP
(Fig. 2). These two villages are also near a major road network linking ANP and other parts of the country. An outbreak in these two villages would easily spread to other parts due to its central position in Eastern Rwanda and the nearby road network.

\section{Discussion}

\section{Vaccinating calves younger than 12 months}

The trivalent (SAT1, SAT2 and O) Kenyan vaccine has been used to vaccinate cattle in Eastern Rwanda once a year. In the case of an FMD outbreak, a ring vaccination targeting cattle in the area has been practised. FMD vaccines are provided to farmers and subsidised by the government and this mitigates the risk of leaving behind some farms unvaccinated. Approximately $40 \%$ of the respondents were found not to vaccinate calves younger than 12 months during the vaccination programs. There may be a perception that calves are less impacted by FMD hence leading farmers to be reluctant in including them into vaccination programs [21]. A further study to 
Table 2 Univariable model for risk factors for the occurrence of FMD outbreaks in herds raised in Eastern Rwanda

\begin{tabular}{llll}
\hline Parameter description & Estimate & Standard error & Significance \\
\hline Natural breeding & 0.486 & 0.3876 & 0.21 \\
Artificial insemination & 0 & & 0.046 \\
Vaccinate calves under 12 months & -0.347 & 0.1738 & 1.626 \\
Not vaccinating calves under 12 months & 0 & & 0.163 \\
Presence of small ruminants & 0.406 & 0.291 & 0.707 \\
Absence of small ruminants & 0 & 0.583 & 0.659 \\
Farm adjacent to another & -0.257 & & 0.274 \\
Farm isolated & 0 & 0.186 & 0.773 \\
Not zero-grazing & -0.204 & & 0.720 \\
Zero-grazing & 0 & 0.712 & 0.816 \\
Farm fenced & -0.255 & & 0.028 \\
Farm not fenced & 0 & 0.571 & 0.775 \\
Farm adjacent to the park & -1.255 & & 0.285 \\
Farm not adjacent to the park & 0 & & \\
\hline
\end{tabular}

understand what would have made a farmer not to include calves into vaccination programs is needed. Our data analysis revealed that failure to vaccinate calves younger than 12 months significantly increased the risks of FMD occurrence in the farms. This finding is consistent with previous studies in which vaccination of calves below 12 months have been found to enhance the protection of herds against FMD outbreaks $[13,25]$. Hence, the ideal would be to clearly state with a data-backed decision at what age vaccination would not interfere with maternal antibodies and with a mature immune system to optimally respond to vaccination. Following the vaccine manufacturer's instructions would have made this risk factor less confounding. Therefore, we recommend conducting more vaccinations a year as per the manufacturer's instructions and regular vaccine matching studies. We also recommend a sensitization to farmers to include animals of all ages in vaccination and at least two vaccinations campaigns a year with booster doses.

\section{Mixed farms}

Rearing of cattle together with sheep and goat in the same farm has been documented to be one of the risk

Table 3 The proportion of farms for each farming systems practised in Nyagatare and Gatsibo districts of Eastern Rwanda and the impact on FMD outbreaks

\begin{tabular}{cll}
\hline & \multicolumn{2}{c}{ Farming system } \\
\cline { 2 - 3 } & $\begin{array}{l}\text { Zero-grazing } \\
\text { Number of farms (\%) }\end{array}$ & Semi zero-grazing \\
\hline At least one outbreak in the last 5 years & \\
Yes & $16 / 40(40)$ & $20 / 102(19.6)$ \\
No & $24 / 40(60)$ & $82 / 102(80.4)$ \\
Total & $40(27.97)$ & $102(71.33)$ \\
\hline
\end{tabular}

factors responsible for FMD outbreak and transmission [26]. This may be a result of the fact that small ruminants show less severe clinical signs of FMD and are not usually included in vaccination programs [27, 28]. Balinda and colleagues (2009) reported a high prevalence of FMDV in small ruminants in Uganda and this has been linked to FMD outbreaks in cattle [29]. Our results flow in the same direction as the above findings in other places. Furthermore, in our study area, we have observed that small ruminants are reared separately from cattle, they tend to go more often and farther outside the farm for grazing and watering. However, the figures above lack a statistical significance to assert the above facts in this case. The low FMD rate may be because the 13/143 (9.09\%) non-mixed farms were small-scale dairy farms, this may be the reason for the lower rate of FMD [21]. Therefore, considering the vaccination regime and the high number of small ruminants in Eastern Province, a deeper investigation on the role played by small ruminants could provide a basis for better control of FMD. From this, policy-makers would decide on whether to conduct more regular vaccination of only cattle with high-quality vaccines or if it is necessary to also include small ruminants in vaccination. Due to a cultural taboo for traditional cattle pastoralists to keep pigs, farmers in our study area reported not to keep pigs. We suggest further studies to focus on the role played by pigs in other regions of Rwanda.

\section{Breeding methods}

There are reports that breeding methods using AI and natural breeding is responsible for the spread of FMD during outbreaks $[30,31]$. However, testing and monitoring of bulls to provide pathogen-free semen could 


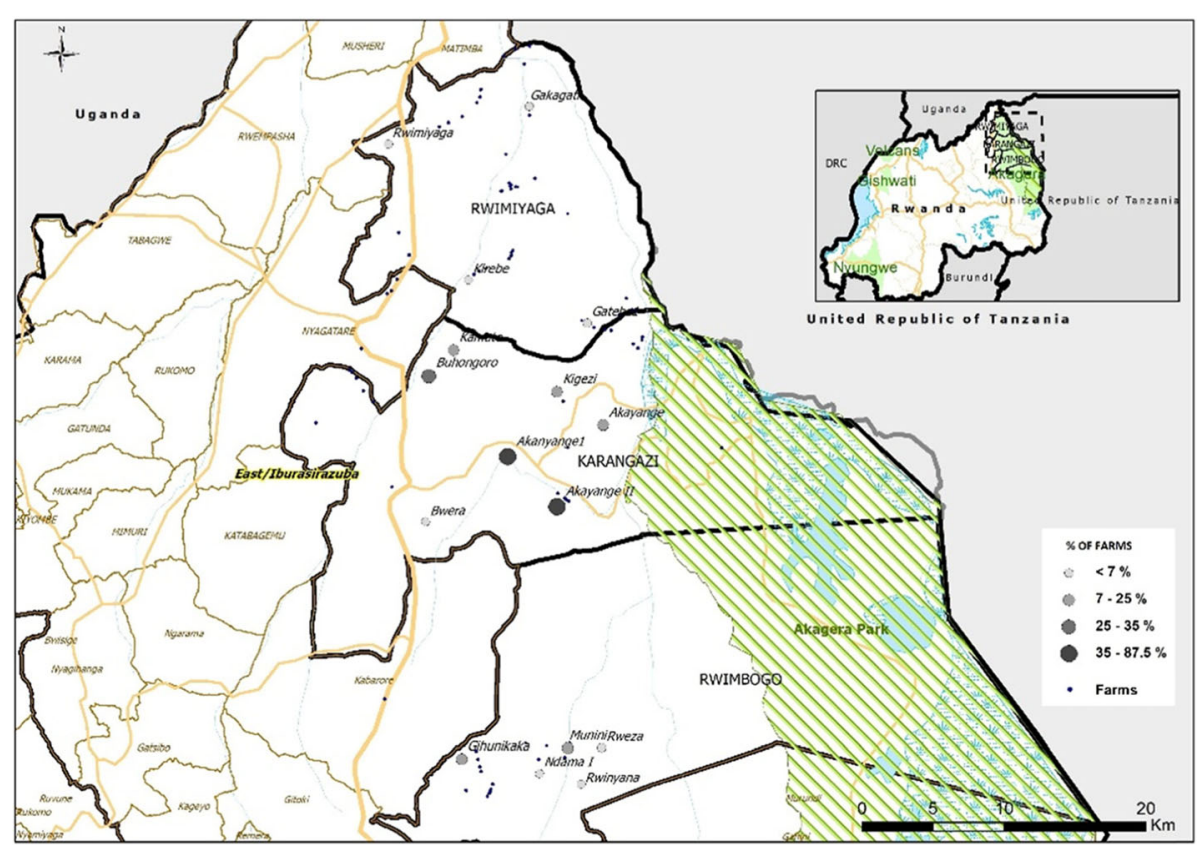

Fig. 2 Map showing the proportion of farms at the interface with ANP per village in Eastern Rwanda (map created using QGIS v. 2.18.22 (https://qgis.org/downloads/))

reduce the risk [32]. Indeed, we observed the AI centres used by the farmers usually screen the bulls for a range of animal infectious diseases including FMD; thereby reducing the risk of the disease transmission. However, further studies on the role of AI on the FMD transmission risk in Eastern Rwanda is still needed to confirm our results.

\section{Seasonality of FMD outbreaks and farming system}

Most of the farmers interviewed reported the likeliness of more outbreaks during the dry season than in the wet season. Indeed, this finding is consistent with official records of the Rwanda Agriculture Board (Personal communication). In addition to OIE reports [14, 24], other studies have also reported more outbreaks of the disease during the dry season as opposed to the wet season [26, 33, 34]. Previous studies have documented that common watering point can provide a means for trans-farm transmission and spread of FMD $[33,35]$ and this is usually observed during prolonged droughts as reported in one study in Tanzania [36]. According to our observation, the trend in the area was to have a common valley dam where animals from different farms go to drink. The daily gathering of animals from different farms, as we observed during this study, was an important trend that can be responsible for disease spread. Other previous studies have also reported that herd contacts at watering points can be a risk for the introduction, spread and persistence of FMD [26, 35, 37, 38]. A previous study has established that uncontrolled cattle movements in East Africa are one of the risk factors responsible for the transmission and spread of FMD in the region [39]. To mitigate this problem, digging water dams or well within the farms seems to be an appropriate solution. Access to water on the farm is not always easy and affordable, especially to small-scale farmers. In India and Ethiopia, a subsidised system of solar-powered pumps has been adopted to provide water to the farms [40, 41].

\section{Proximity of farms to each other}

FMD is usually spread by contact and to some extent by airborne means. Therefore, the transmission and spread of FMD during outbreaks tend to be faster in farms located close to each other [42-45]. Though many farms are adjacent to another farm in this study area, with a high $p$ value, we did not find the results to be conclusive. Hence, we commend further investigations to look into this aspect. This may be because airborne transmission is much less when compared to direct contact transmission such as meeting at communal watering points. Previous studies have suggested that low humidity and high temperature could be responsible for reduced transmission of FMDV $[46,47]$. Subsequently, it is possible that Eastern Rwanda may experience reduced FMD outbreaks when humidity is low and the temperature is high.

\section{Wildlife-livestock interface}

Previous studies in Southern African countries have reported that wildlife, especially African buffaloes, are carriers of FMD virus indicating that the animals could be a source for the transmission of the virus [31, 48-52]. This 
often happens when cattle graze near the parks in the Southern African countries, especially during the dry season. In Southern African countries, the problem of wildlife-livestock interaction has been solved by fencing the national parks found in these countries to minimize contacts between wildlife and livestock [53]. Therefore, in order to reduce the human-wildlife-livestock interactions in Rwanda, the fencing approach has also been adopted particularly in Eastern Rwanda [54]. In this case, the Rwanda Development Board used an electric fence to separate the ANP from the livestock farmers. However, as we observed, some buffaloes were left outside the fenced park during the fencing programme. Nevertheless, there was not an immediate effect observed for farms adjacent to the ANP when compared to other farms in the study, probably park fencing mitigated this risk. Up to date, no laboratory-based results is pointing to the role played by buffaloes in Rwanda is available. A Pirbright research group suggested in 2018 that the role of African buffaloes in the transmission of FMD in East African might be different from what has been reported in Southern Africa countries. The latter study proposed a different control measure involving vaccination of cattle before an outbreak, as "a region-tailored" solution [55]. This proposal is supported by our findings, in which we surprisingly found that more farms have had FMD than the ones adjacent to the ANP fence. This can be linked to several factors such as that farms adjacent to the park are far from borders with less effect of transboundary animal movements. Moreover, ANP has been fenced since 2013 reducing the wildlife-livestock contact.

\section{Maps of selected risk factors}

The mapping of risk factors is an important tool for understanding the epidemiology of FMD. The mapping has been used for generating a spatio-temporal distribution of the risk factors as reported in different parts of the world [26, 56-58]. Generating thematic maps of risk factors has also been reported to be of paramount importance in modelling and zoning of the disease in some countries $[20,58]$. There is no previous study done to map the risk factors in Eastern Rwanda.

Rwinyana village of Gatsibo district is the only one among all the villages with fewer farms $(<75 \%)$ that are not close to each other (Fig. 1c). Akayange I and Akayange II villages in Nyagatare district are the ones with a higher proportion of farms at the interface with ANP (Fig. 2). These two villages are also near a major road network linking ANP and other parts of the country. An outbreak in these two villages would easily spread to other parts due to its central position in Eastern Rwanda and the nearby road network. For instance, infected cattle crossing roads to the watering points would leave infectious material behind that can attach to the tire surfaces of passing by vehicles. There is a need to confirm if farmers living near major roads move their animals more often than the farmers living far from major roads. In Nyagatare district, only $6 \%$ of the farmers have watering-points on their farms [59]. We believe that the use of on-farm watering-points would reduce the dependence on communal water points and hence reduce the odds of FMD transmission between different herds as reported previously [60, 61].

\section{Conclusion}

We conclude that vaccinating calves under 12 months would protect the herds from the incursion of FMD. Therefore, we recommend vaccination programs that target both older and younger cattle, particularly following manufacturers' instructions. Besides, farmers are aware that dry seasons are riskier than rainy seasons as long as FMD outbreaks are concerned. The proximity of farms to ANP or other farms including mixed farms that rear both cattle and small ruminants appear not to be statistically significant as risk factors. Further studies on the incursion of FMD in the area should focus on the role played by the domestic-wildlife interaction, the closeness of adjacent farms, the breeding system and awareness of farmers.

\section{Methods}

\section{Study area}

Nyagatare and Gatsibo districts experience low rainfall amounts with fewer rivers and are home to ANP, which has a considerable number of domestic and wildlife animals including African buffaloes (Syncerus caffer). The study area falls in the triangle neighbouring three countries namely, Tanzania, Rwanda and Uganda indicating risks for uncontrolled transboundary movements of animals between these countries. Since 1994, almost all of the reported FMD outbreaks (1996-1997, 2000-2001, 2004, 2005, 2006, 2013, 2015 and 2017) in the country have happened in Eastern Rwanda. Besides, in all these cases, biological samples were collected and taken to the laboratory to confirm the outbreak and detect the causative serotype(s) in laboratories.

\section{Study design}

We designed a questionnaire [see Additional file 1] based on previously published papers on risk factors. Also, the Food and Agriculture Organization's European Commission for the Control of FMD online document on FMD Investigation was used and is available at https://eufmdlearning.works/ [62]. The questionnaire covered several risk factors including farms not vaccinating calves less than 12 months of age, mixed farms keeping small and large ruminants [61], breeding system, seasonality of FMD outbreaks 
and farming systems [35, 63], farm adjacent to each other [64] as well as the wildlife-livestock interface [35]. In this study, zero-grazing stands for the system where livestock are reared inside the farm and water is available within the farm boundaries. Semi-zero grazing is for farmers who feed their animals within their farms' boundaries but move their animals to communal watering points. Lastly, free-ranging is for farmers who graze and water their animals outside their farms. Most farmers in the area cultivate fodder mainly Napier grass (93.2\%) [65].

\section{Target population and questionnaire administration}

This study applied a cross-sectional study design and data were collected from Nyagatare and Gatsibo villages based on their proximity to ANP. A questionnaire was administered to all cattle farmers within the selected area covering $20 \mathrm{~km}$ distance from the electric fence of the ANP. This area covered the wildlife livestock interface where domestic and wildlife animals, especially African buffaloes, are likely to interact. We conducted interviews between May 2018 and August 2018. The information collected was documental on a paper-based questionnaire translated in Kinyarwanda and later entered in a spreadsheet of the Statistical Product and Service Solutions (SPSS Inc., IL, USA) version 16.0. The questionnaire had both open-ended and closed questions and was pre-tested on a smaller number of respondents to check for the clarity of the questions. Before each interview, respondents gave their verbal consent to proceed with the interview, after being briefed on the objectives and the expected outcomes of the study. The geographical coordinates of the farms were recorded using a Smartphone Application (Global Positioning System Coordinates Finder by EzgApps). Using the geographical coordinates, maps were created in QGIS v. 2.18.22 (Las Palmas, USA).

\section{Data analysis}

Data were coded in SPSS (SPSS Inc., IL, USA) for analysis, the codes were extensively revised to make sure that they are relevant based on the responses given by the farmers during the questionnaire administration. The descriptive statistics including proportion, means and categories of risk factors were generated. Data were also summarized using graphs. Inferential statistics such as chi-square $(\mathrm{X} 2)$ test was used to analyse the variables using the SPSS software (SPSS Inc., IL, USA). Where applicable, univariable and multivariable analyses were performed to estimate odds ratios (OR), using a criterion of whether a farm had experienced FMD outbreak in the last 5 years with a confidence interval of $95 \%$.

\section{Supplementary information}

Supplementary information accompanies this paper at https://doi.org/10. 1186/s12917-020-02610-1.

Additional file 1. Questionnaire form for cattle farmers in Eastern Rwanda: this is the English version of the paper-based questionnaire that we developed and used to collect information for this study.

\begin{abstract}
Abbreviations
FMD: Foot-and-Mouth Disease; FMDV: Foot-and-Mouth Disease Virus; QGIS: Quantum Geographic Information System; OR: Odd Ratio; SAT: Southern African Territories; PCP-FMD: Progressive Control Pathway for Foot-and-Mouth Disease; ANP: Akagera National Park; SPSS: Statistical Product and Service Solutions; Al: Artificial Insemination; Cl: Confidence Interval
\end{abstract}

\section{Acknowledgements}

The authors acknowledge the farmers that wilfully responded to the questions.

\section{Authors' contributions}

All authors have equally contributed to the manuscript writing and data analysis of this study. JCU participated in the study design, data collection, manuscript writing, data analysis and creating maps. GOA, GOO and PJL participated in the manuscript writing, supervision, data analysis and manuscript revision. JO participated in manuscript writing and data analysis. MP participated in creating maps. All authors have read and approved the manuscript.

\section{Funding}

This material is based upon work supported by the United States Agency for International Development, as part of the Feed the Future initiative, under the CGIAR Fund, award number BFS-G-11-00002, and the predecessor fund the Food Security and Crisis Mitigation II grant, award number EEM-G-00-0400013. The funder supported the data collection phase of this work.

\section{Availability of data and materials}

The dataset backing the findings is available on https://figshare.com/articles/ dataset/FMD_Risk_Factor_consolidated_data/12756134

\section{Ethics approval and consent to participate}

This research was approved by the Directorate of Research and Innovation of the University of Rwanda-College of Agriculture, Animal Sciences and Veterinary Medicine (UR-CAVM). It was also approved by the Animal Resources Department of the Rwanda Agriculture Board (N01.11/004FMD/017/CK HoD-ARD). Before each interview, respondents were explained that the study had no other intention other than research and they were verbally asked if they consent to continue with the interview. The verbal consent was preferred and approved over the written consent due to some respondents who would not be able to read the declaration. The verbal consent reception was testified by a third independent party in the person of Sector Veterinary Officer present during the interviews.

\section{Consent for publication}

Not applicable.

\section{Competing interests}

The authors declare that there are no competing interests.

\section{Author details}

${ }^{1}$ Centre for Biotechnology and Bioinformatics, University of Nairobi, P.O. Box 30197, Nairobi, Kenya. ${ }^{2}$ Department of Veterinary Medicine, University of Rwanda, P.O. Box 57, Nyagatare, Rwanda. ${ }^{3}$ Department of Public Health, Pharmacology and Toxicology, Faculty of Veterinary Medicine, University of Nairobi, P.O. Box 29053, Nairobi, Kenya. ${ }^{4}$ TokaBio (Pty), Ltd, Pretoria, South Africa. ${ }^{5}$ Food and Agriculture Organization of the United Nations, Viale delle Terme di Caracalla, Rome, Italy. 
Received: 23 March 2020 Accepted: 5 October 2020

Published online: 12 October 2020

\section{References}

1. Grubman M, Baxt B. Foot-and-mouth disease. Clin Microbiol Rev. 2004;17(2): 465-93 Available from: http://cmr.asm.org/content/17/2/465.short.

2. Weaver G V, Domenech J, Thiermann AR, Karesh WB. Foot and mouth disease: a look from the wild side. J Wild Dis. 2013;49(4):759-785. Available from: https://www.jwildlifedis.org/doi/pdf/10.7589/2012-11-276.

3. Rweyemamu M, Roeder P, Mackay D, Sumption K, Brownlie J, Leforban Y, et al. Epidemiological patterns of foot-and-mouth disease worldwide. Transbound Emerg Dis. 2008;55(1):57-72 Available from: https://pubmed. ncbi.nlm.nih.gov/18397509/.

4. World Reference Laboratory for Foot and Mouth Disease. Rwanda [Internet]. World Reference Laboratory for Foot and Mouth Disease Country Report. Available from: https://www.wrlfmd.org/east-africa/rwanda\#panel-9621. [cited 2020 Jan 28].

5. Foot and Mouth outbreak feared. The New Humanitarian. 2001. Available from: http://www.thenewhumanitarian.org/report/18013/rwanda-foot-andmouth-outbreak-feared [cited 2020 Jan 28].

6. Rwembeho S. Foot-and-mouth disease confirmed in E. Province. Kigali: The New Times Publications; 2015. Available from: https://www.newtimes.co.rw/ section/read/186884 [cited 2020 Jan 28].

7. Ntirenganya E. Foot and mouth disease: Livestock movement banned in E. Province. Kigali: The New Times Publications SARL; 2017. Available from: https://www.newtimes.co.rw/section/read/212663.

8. Mbaraga R. Animal movement ban on after foot, mouth outbreak. The East African. 2017. Available from: https://www.theeastafrican.co.ke/rwanda/ News/Animal-movement-ban-on-after-outbreak/1433218-3960802-ra0msxz/ index.html [cited 2020 Jan 28].

9. AU-IBAR. Foot-and-Mouth Disease in Ruminants. 2013. Available from: https://www.au-ibar.org/foot-and-mouth-disease-in-ruminants. [cited 2020 May 30].

10. FAO/EuFMD. Global Monthly Report on FMD December 2017. Rome: European Commission for the Control of Foot-and-Mouth Disease; 2017. Available from: http://www.fao.org/fileadmin/user_upload/eufmd/FMD_ reports GMR/Dec2017.pdf.

11. Sumption K, Domenech J, Ferrari G. Progressive control of FMD on a global scale. Vet Rec. 2012;170(25):637-9. https://doi.org/10.1136/vr.e4180.

12. MINAGRI. Ministry of Agriculture and Animal Resources Annual Report Financial Year 2014-2015. 2015.

13. Elnekave E, Zamir L, Hamd F, Even Tov B, Klement E. Risk factors for foot and mouth disease outbreaks in grazing beef cattle herds. Prev Vet Med. 2015;120(2):236-40.

14. OIE (World Organisation for Animal Health). Foot and mouth disease, Rwanda; 2020. p. 1. Available from: https://www.oie.int/wahis_2/public/ wahid.php/Reviewreport/Review?page_refer=MapFullEventReport\&reportid= 34885\&newlang=en [cited 2020 Jul 14].

15. FAO/EuFMD. Global Monthly Report on FMD November 2018. Rome: Food and Agriculture Organization (FAO); 2018. Available from: http://www.fao.org/ fileadmin/user_upload/eufmd/FMD_reports_GMR/November_GMR_2018.pdf.

16. Kerfua SD, Shirima G, Kusiluka L, Ayebazibwe C, Mwebe R, Cleaveland S, et al. Spatial and temporal distribution of foot-and-mouth disease in four districts situated along the Uganda - Tanzania border : implications for cross-border efforts in disease control. Onderstepoort J Vet Res. 2018;85(1): 1-8 Available from: http://www.scielo.org.za/pdf/ojvr/v85n1/08.pdf.

17. Paton DJ, Sumption KJ, Charleston B. Options for control of foot-and-mouth disease: knowledge, capability and policy. Philos Trans R Soc B Biol Sci. 2009;364(1530):2657-67 Available from: https://www.ncbi.n/m.nih.gov/pmc/ articles/PMC2865093/pdf/rstb20090100.pdf.

18. Ayebazibwe C, Tjørnehøj K, Mwiine FN, Muwanika VB, Ademun Okurut AR, Siegismund HR, et al. Patterns, risk factors and characteristics of reported and perceived foot-and-mouth disease (FMD) in Uganda. Trop Anim Health Prod. 2010;42(7):1547-59 Available from: http://link.springer.com/10.1007/ s11250-010-9605-3

19. Allepuz A, Stevenson M, Kivaria F, Berkvens D, Casal J, Picado A. Risk factors for foot-and-mouth disease in Tanzania, 2001-2006. Transbound Emerg Dis. 2015;62(2):127-36.

20. Picado A, Speybroeck N, Kivaria F, Mosha RM, Sumaye RD, Casal J, et al. Foot-and-mouth disease in Tanzania from 2001 to 2006. Transbound Emerg Dis. 2011;58(1):44-52.
21. Nyaguthii DM, Armson B, Kitala PM, Sanz-Bernardo B, Di Nardo A, Lyons NA. Knowledge and risk factors for foot-and-mouth disease among small-scale dairy farmers in an endemic setting. BMC Vet Res. 2019;50(1):33 Available from: https://veterinaryresearch.biomedcentral.com/articles/10.1186/s13567019-0652-0.

22. Ngabonziza G. A Critical Investigation Of Conservation Attitudes Of The Local Community Living Adjacent To Akagera National Park, Rwanda. Cape Town: Cape Peninsula University of Technology; 2010. Available from: https://core.ac.uk/download/pdf/148365463.pdf.

23. KEVEVAPI. Kenya Veterinary Vaccine Production Institute-FOTIVAX Vaccine. 2020. Available from: https://kevevapi.or.ke/product/fotivax-tm/ [cited 2020 May 31].

24. Weaver J, Facelli P, Letshwenyo M. OIE PVS evaluation follow-up Mission report, Rwanda. Paris; 2019. Available from: https://www.oie.int/fileadmin/ Home/eng/Support to OIE_Members/pdf/20191218_Rwanda_PVS_FU report_2019_final.pdf.

25. Dekker A, Eblé P, Stockhofe N, Chénard G. Intratypic heterologous vaccination of calves can induce an antibody response in presence of maternal antibodies against foot-and-mouth disease virus. BMC Vet Res. 2014;10:2-6 Available from: https://bmcvetres.biomedcentral.com/track/ pdf/10.1186/1746-6148-10-127.

26. Wungak YS, Olugasa BO, Ishola OO, Lazarus DD, Ularamu GH. Foot-andmouth disease (FMD) prevalence and exposure factors associated with seropositivity of cattle in north-central , Nigeria. Afr J Biotechnol. 2016; 15(24):1224-32 Available from: http://www.academicjournals.org/AJB.

27. Kitching RP, Hughes GJ. Clinical variation in foot and mouth disease: sheep and goats. OIE Rev Sci Tech. 2002;21(3):505-12.

28. Barnett PV, Cox SJ. The role of small ruminants in the epidemiology and transmission of foot-and-mouth disease. Vet J. 1999;158(1):6-13 Available from: http://www.idealibrary.com

29. Balinda SN, Tjørnehøj K, Muwanika VB, Sangula AK, Mwiine FN, Ayebazibwe C. Prevalence estimates of antibodies towards foot-and-mouth disease virus in small ruminants in Uganda. Transbound Emerg Dis. 2009;56:362-71.

30. Callis JJ. Evaluation of the presence and risk of foot and mouth disease virus by commodity in international trade. Rev Sci Tech I'OIE. 1996;15(3):1075-85 Available from: https:/doc.oie.int/dyn/portal/index.seam?page=alo\&alold=28512.

31. Paton DJ, Gubbins S, King DP. Understanding the transmission of foot-andmouth disease virus at different scales. Curr Opin Virol 2018;28:85-91. Available from: https://doi.org/10.1016/j.coviro.2017.11.013.

32. Guérin B, Pozzi N. Viruses in boar semen: detection and clinical as well as epidemiological consequences regarding disease transmission by artificial insemination. Theriogenology. 2005;63(2):556-72 Available from: https:// linkinghub.elsevier.com/retrieve/pii/S0093691X04003218.

33. Waret-Szkuta A, Ortiz-Pelaez A, Pfeiffer DU, Roger F, Guitian FJ. Herd contact structure based on shared use of water points and grazing points in the highlands of Ethiopia. Epidemiol Infect. 2011;139:875-85.

34. Tekleghiorghis T, Moormann RJM, Weerdmeester K, Dekker A. Foot-andmouth disease transmission in Africa: implications for control, a review. Transbound Emerg Dis. 2014;63(2):136-51.

35. Bronsvoort BD, Nfon C, Hamman SM, Tanya VN, Kitching RP, Morgan KL Risk factors for herdsman-reported foot-and-mouth disease in the Adamawa Province of Cameroon. Prev Vet Med. 2004;66(1-4):127-39 Available from: https://pubmed.ncbi.nlm.nih.gov/15579340/.

36. Kivaria FM. Foot and mouth disease in Tanzania : an overview of its national status foot and mouth disease in Tanzania : an overview of its national status. Vet Q. 2003;25(2):72-8

37. Abbas T, Younus M, Muhmmad SA, ljaz M, Shakoor A. Some challenges to progressive control of foot and mouth disease in Pakistan--findings of a pilot survey. Transbound Emerg Dis. 2014;61(1):81-5 Available from: http:// doi.wiley.com/10.1111/tbed.12008.

38. Bayissa B, Ayelet G, Kyule M. Study on seroprevalence, risk factors, and economic impact of foot-and-mouth disease in Borena pastoral and agropastoral system, southern Ethiopia. Trop Anim Health Prod. 2011;43:759-66.

39. Baluka SA, Hisali E, Wasswa F, Ocaido M, Mugisha A. Socio-economic risk factors associated with foot and mouth disease, and contagious bovine pleuropneumonia outbreaks in Uganda. Livest Res Rural Dev. 2013;25(12) Available from: http://www.Irrd.org/Irrd25/12/balu25214.htm.

40. Bird J, Roy S, Shah T, Aggarwal P, Smakhtin V, Amarnath G, et al. Adapting to climate variability and change in India. In: Biswas A, Tortajada C, editors. Water resources development and management. Springer: Singapore; 2016. p. 41-63. 
41. Giordano $M$, Ünver $\mathrm{O}$, Barron J. Four reasons small farms are running out of water and how we can fix it. 2019. Available from: https://wle.cgiar.org/ thrive/2019/01/15/four-reasons-small-farms-are-running-out-water---andhow-we-can-fix-it [cited 2020 Jul 15].

42. Wang $Y$, Jiang $Z$, Jin Z, Tan $H$, Xu B. Risk factors for infectious diseases in backyard poultry farms in the Poyang Lake area, China. PLoS One. 2013;8(6): $1-10$.

43. Rossi G, Smith RL, Pongolini S, Bolzoni L. Modelling farm-to-farm disease transmission through personnel movements: from visits to contacts, and back. Sci Rep. 2017;7(1):1-11.

44. Lyytikäinen T, Niemi JK, Sahlström L, Virtanen T, Rintakoski S, Kyyrö J, et al. The effects of structural change in agriculture on the spread of animal disease in Finland [internet]. 2015. Available from: http://hdl.handle.net/1013 $8 / 157820$

45. Lyytikäinen T, Niemi J, Sahlström L, Virtanen T, Lehtonen H. The spread of Foot-and-mouth disease (FMD) within Finland and emergency vaccination in case of an epidemic outbreak. Evira Research Reports 1/2011. 2011. Available from: http://hdl.handle.net/10138/44654.

46. Sørensen JH, Mackay DKJ, Jensen C, Donaldson Al. An integrated model to predict the atmospheric spread of foot-and-mouth disease virus. Epidemiol Infect. 2000;124(3):577-90.

47. Sutmoller P, Barteling SS, Casas R, Sumption KJ. Control and eradication of foot-and-mouth disease, vol. 91; 2003.

48. Condy JB, Hedger RS, Hamblin C, Barnett IT. The duration of the foot-andmouth disease virus carrier state in African buffalo (i)in the individual animal and (ii) in a free-living herd. Comp Immunol Microbiol Infect Dis. 1985;8(3): 259-65 Available from: https://pubmed.ncbi.nlm.nih.gov/3004803/.

49. Thomson GR, Vosloo W, Esterhuysen JJ, Bengis RG. Maintenance of foot and mouth disease viruses in buffalo in southern Africa. Rev Sci Tech. 1992;11(4): 1097-107 Available from: https://doc.oie.int/dyn/portal/index.seam?page= alo\&alold $=26244$.

50. Vosloo W, Bastos AD, Kirkbride E, Esterhuysen JJ, van Rensburg DJ, Bengis $R G$, et al. Persistent infection of African buffalo ( Syncerus caffer ) with SATtype foot-and-mouth disease viruses : rate of fixation of mutations, antigenic change and interspecies transmission. J Gen Virol. 1996;77:145767.

51. Thomson GR, Penrith ML, Atkinson MW, Atkinson SJ, Cassidy D, Osofsky SA. Balancing livestock production and wildlife conservation in and around southern Africa's Transfrontier conservation areas. Transbound Emerg Dis. 2013;60(6):492-506.

52. Thomson G, Vosloo W. Natural Habitats in Which Foot-and-Mouth Disease Virus is Maintained. In: Foot and Mouth Disease. Domingo, E. Boca Raton: CRC Press; 2004. p. 384-410. Available from: http://www.crcnetbase.com/ doi/10.1201/9781420037968.ch14.

53. Jori F, Etter E. Transmission of foot and mouth disease at the wildlife / livestock interface of the Kruger National Park, South Africa : Can the risk be mitigated ? Prev Vet Med 2016;126:19-29. Available from: https://doi.org/ 10.1016/j.prevetmed.2016.01.016.

54. The New Times. New Akagera Park electric fence to mitigate human-wildlife conflict. Kigali: The New Times Publications SARL; 2013. Available from: https://www.newtimes.co.rw/section/read/68986.

55. Casey-bryars M, Reeve R, Bastola U, Knowles NJ, Auty H, Bachanekbankowska K, et al. Waves of endemic foot-and-mouth disease in vaccination approaches. Nat Ecol Evol. 2018;2(9):1449-57 Available from: https://www.nature.com/articles/s41559-018-0636-x.

56. Carvalho LM, Faria NR, Perez AM, Suchard MA, Lemey P, Silveira WDC, et al. Spatio-temporal Dynamics of Foot-and-Mouth Disease Virus in South America. Virus Evol. 2015:1-21. arXiv:1505.01105v2 [q-bio.PE]. Available from: https://arxiv.org/abs/1505.01105.

57. Cottam EM, Wadsworth J, Shaw AE, Rowlands RJ, Goatley L, Maan S, et al. Transmission pathways of foot-and-mouth disease virus in the United Kingdom in 2007. PLoS Pathog. 2008;4(4):e1000050.

58. AU-IBAR. Standard Methods and Procedures (SMPs) for Control of Foot and Mouth Disease in the Greater Horn of Africa. Nairobi; 2014.

59. Mazimpaka E. Characterization of cattle production Systems in Eastern Province, Rwanda; a case study in Nyagatare District. Kampala: Makerere University; 2017. Available from: https://www.researchgate.net/ publication/324080647_Characterization_of_Cattle_Production_Systems_in Eastern_Province_Rwanda_a_case_study_in_Nyagatare_District.

60. Miller CAJ, Young JR, Nampanya S, Khounsy S, Singanallur NB, Vosloo W, et al. Risk factors for emergence of exotic foot-and-mouth disease O/ME-
SA/Ind-2001d on smallholder farms in the greater Mekong subregion. Prev Vet Med. 2018;159:115-122. Available from: https://doi.org/10.1016/j. prevetmed.2018.09.007.

61. Megersa B, Beyene B, Abunna F, Regassa A, Amenu K, Rufael T. Risk factors for foot and mouth disease seroprevalence in indigenous cattle in southern Ethiopia: the effect of production system. Trop Anim Health Prod. 2009; 41(6):891-8.

62. FAO/EuFMD. Foot and Mouth Disease Training Course . 2018. Available from: https://eufmdlearning.works/login/index.php? [cited 2018 May 31]

63. Dukpa K, Robertson I, Edwards J, Ellis T, Tshering P, Rinzin K, et al. Risk factors for foot-and-mouth disease in sedentary livestock herds in selected villages in four regions of Bhutan risk factors for foot-and-mouth disease in sedentary livestock herds in selected villages in four regions of Bhutan. N Z Vet J 2011;59(2):51-58. Available from: https://doi.org/10.1080/00480169. 2011.552852.

64. Boender GJ, Hagenaars TJ, Bouma A, Nodelijk G, Elbers ARW, De Jong MCM, et al. Risk maps for the spread of highly pathogenic avian influenza in poultry. PLoS Comput Biol. 2007;3(4):704-12.

65. Mazimpaka E, Mbuza F, Tukei M, Gatari E, Bukenya E, Okwee-Acai J. Current status of cattle production system in Nyagatare District-Rwanda. Trop Anim Health Prod. 2017;8(49):1645-56.

\section{Publisher's Note}

Springer Nature remains neutral with regard to jurisdictional claims in published maps and institutional affiliations.
Ready to submit your research? Choose BMC and benefit from:

- fast, convenient online submission

- thorough peer review by experienced researchers in your field

- rapid publication on acceptance

- support for research data, including large and complex data types

- gold Open Access which fosters wider collaboration and increased citations

- maximum visibility for your research: over $100 \mathrm{M}$ website views per year

At BMC, research is always in progress.

Learn more biomedcentral.com/submissions 